\title{
Risperidone Induced Xerosis and Tachycardia in Schizophrenia Patients: A Case Report
} Bangunawati Rahajeng ${ }^{1, *}$ Pinasti Utami ${ }^{2}$ Astrit Ikafitriani ${ }^{3}$

\author{
1,2 Department of Pharmacology and Clinical Pharmacy, School of Pharmacy, Faculty of Medicine and Health Sciences, \\ Universitas Muhammadiyah Yogyakarta \\ ${ }^{3}$ Department of Pharmacy Ghrasia Hospital, Yogyakarta Special Region \\ ${ }^{*}$ Corresponding author. Email: bangunawati.r@umy.ac.id
}

\begin{abstract}
Background: Risperidone is one of the atypical antipsychotics usually used in schizophrenia therapy. Like most antipsychotics, risperidone has several side effects. Xerosis and tachicardy are rare side effects of Risperidone with incidence < $1 \%$. However unfortunately, the numbers of case reports about risperidone's side effects are very limited, especially in Indonesia. The case report aims to inform the health professionals about the side effect of risperidone in Schizophrenia patienst in Indonesia.

Case presentation: A 54-year-old woman was hospitalized with a diagnosis of schizophrenia. The patient received risperidone $2 \mathrm{mg}$, clozapine $25 \mathrm{mg}, 1 / 2$ ampule haloperidol injection, cetirizine $10 \mathrm{mg}$, methylprednisolone $4 \mathrm{mg}$, amlodipine $5 \mathrm{mg}$. On the following day, the patient experienced itching, hardening of the facial skin and tachycardia (pulse 124). The Naranjo score for riperidone was 6 (probably). After the incident, the physicians stopped the risperidone. The patient was then prescribed a facial lotion to treat her dry and peeling facial skin. After discontinuing the risperidone, the patient's facial skin condition improved, and the pulse was normal.

Conclusion: Risperidone is known to have side effects of xerosis and tachycardia in these patients, so healthcare professionals should monitor the use of risperidone and other antipsychotics to anticipate potential side effects.
\end{abstract}

Keywords: risperidone, schizophrenia, side-effects, tachycardia, xerosis

\section{BACKGROUND}

According to WHO, Schizophrenia is a mental illness characterized by disturbances in thinking, emotional disorders, language, taste, and behavior. The symptoms of schizophrenia include delusions and hallucinations. Schizophrenia affects nearly 20 million people. Management of Schizophrenia is carried out using pharmacological and non-pharmacological therapies that involve: psychiatrists, psychologists, families, and of course, pharmacists [1].

Pharmacological therapy for schizophrenia usually uses antipsychotics. The choice of antipsychotic depends on the type of schizophrenia, the patient's condition, and many other factors that vary from patient to patient. Remington et al. (2017) divided schizophrenia therapy based on six conditions, namely

1. Early episodes

2. Acute exacerbations

3. Relapse prevention and maintenance therapy

4. Resistant therapy

5. Clozapine resistance.

6. Specific domain symptoms [2]

The choice of antipsychotics used in therapy also depends on the patient's condition, thus there is no definite therapeutic algorithm. In the moment of administering pharmacological therapy, counseling to patients is needed, especially regarding side effects. Antipsychotic drugs have many side effects. The side effects that occur can be acute (dizziness, sedation, and anxiety) or delayed side effects such as cognitive impairment. These side effects frequently aggravate the patient's condition so that the patient often becomes non-adherence to the therapy [3].

Risperidone is one of the antipsychotics that is often used in schizophrenia. Some side-effects of risperidone are categorized as common or very common (>10\%), uncommon $(1 \%-10 \%)$, and rare $(<1 \%)$. Some studies reported the sideeffects of risperidone like fatigue, somnolence, tremor, weight gain, tachycardia, unclassified erythema with a variation of incidence [4-6].

Many patients are not well educated about this drug's side effects. Therefore, this case report was written to provide additional information on the incidence of antipsychotic side effects. This information is expected to become educational material for health workers, patients, and their families who use antipsychotics.

\section{CASE PRESENTATION}

The patient, a 56-year-old woman, was hospitalized on November 4, 2019, at $05.10 \mathrm{pm}$. The patient was taken by his family because she was angry, rowdy, anxious, confused, went out of the house, bought clothes, talked to herself, and attacked people with words. Her history was stage 2 hypertension. At admission, blood pressure was $180 / 84 \mathrm{mmHg}$, pulse $95 \mathrm{x} / \mathrm{minute}$, temperature $36.3^{\circ} \mathrm{C}$, and 
Respiratory Rate (RR) 20x/minute. The patient was diagnosed with Undifferentiated schizophrenia [7]. The patient was treated with risperidone $2 \mathrm{mg}$, clozapine $25 \mathrm{mg}$, haloperidol injection $1 / 2$ amp, cetirizine $10 \mathrm{mg}$, methylprednisolone $4 \mathrm{mg}$, amlodipine $5 \mathrm{mg}$. The data of patient progress can be seen in table 1 .

Table1. Patient Progress

\begin{tabular}{|c|c|c|c|c|c|c|}
\hline Day & Drugs & Condition & $\mathrm{BP}(\mathrm{mm} / \mathrm{Hg})$ & $\mathrm{RR}(\mathrm{x} /$ minute $)$ & $\mathrm{P}(\mathrm{x} /$ minute $)$ & $\mathrm{T}\left({ }^{0} \mathrm{C}\right)$ \\
\hline 1 & \begin{tabular}{|l} 
Risperidone \\
Clozapin \\
Haloperidol inj $1 / 2 \mathrm{mg}$ \\
Cetirizine $10 \mathrm{mg}$ \\
Methylprednisolone \\
Amlodipine $5 \mathrm{mg}$
\end{tabular} & $\begin{array}{l}\text { angry, rowdy, anxious, confused, went out of } \\
\text { the house, bought clothes, talked to herself, } \\
\text { and attacked people with words }\end{array}$ & $180 / 84$ & 20 & 95 & 36.3 \\
\hline 2 & $\begin{array}{l}\text { Risperidone } 2 \mathrm{mg}, \\
\text { Lorazepam } 0,5 \mathrm{mg} \\
\text { Amlodipine } 5 \mathrm{mg} \\
\text { Methylprednisolone } 4 \mathrm{mg} \\
\text { Cetirizine } 10 \mathrm{mg} \\
\text { Clozapine stop }\end{array}$ & $\begin{array}{l}\text { Enough sleep rest, much progress, a negative } \\
\text { sign of violent behavior, relatively calm, and } \\
\text { cooperative. } \\
\text { The patient began to feel itchy, and the face } \\
\text { felt hard. The nutritional status based on the } \\
\text { upper arm's circumference was insufficient; } \\
\text { the food intake was sufficient. }\end{array}$ & $164 / 84$ & & 117 & 36.2 \\
\hline 3 & $\begin{array}{l}\text { injection of haloperidol } 1 \\
\text { amp im /12 hours, } \\
\text { Tri Hexy Phenidyl (THP) } \\
2 \mathrm{mg}, \\
\text { Lorazepam } 0.5 \mathrm{mg} \text {, } \\
\text { Clozapine 100mg } \\
\text { Face lotion } \\
\text { Risperidone stop }\end{array}$ & $\begin{array}{l}\text { The patient's condition deteriorated, spoke } \\
\text { curtly, lacked rest, was angry, had a } 1 / 2 \text { portion } \\
\text { of the diet, and behaved violently. } \\
\text { She wanted to go home and became less } \\
\text { cooperative and autistic. Facial skin began to } \\
\text { peel, and physical complaints increased. }\end{array}$ & $122 / 90$ & 20 & 124 & 36.2 \\
\hline 4 & $\begin{array}{l}\text { Facial lotion, } \\
\text { Amlodipine } 5 \mathrm{mg} \\
\text { Methylprednisolone 4mg } \\
\text { Haloperidol 1.5mg } \\
\text { THP 2mg, 1 } \\
\text { Lrazepam r } \\
\text { Clozapine } \quad 100 \mathrm{mg}, \\
\text { Haloperidol injection } 1 \\
\text { amp/24 hours. } \\
\text { Cetirizine stop }\end{array}$ & $\begin{array}{l}\text { The patient behaved violently and felt her } \\
\text { face blackened due to occult knowledge, } \\
\text { lacked rest, was restless, paced, inter-magic, } \\
\text { hallucination, and autistic, while physical } \\
\text { complaints reduced. } \\
\text { The patient was still at his own pace, } \\
\text { insistent, well-spoken, and somewhat } \\
\text { temperamental }\end{array}$ & & & & \\
\hline 5 & 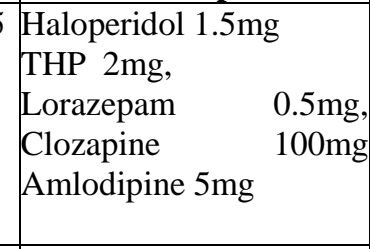 & $\begin{array}{l}\text { The patient began to calm down, cooperative, } \\
\text { positive audio and visual hallucinations, } \\
\text { unrealistic, and poor insight. There were no } \\
\text { physical complaints, and itching on the } \\
\text { cheeks had improved. She got enough rest, } \\
\text { autistic, and had sensory perception disorders }\end{array}$ & $139 / 86$ & & & \\
\hline 6 & 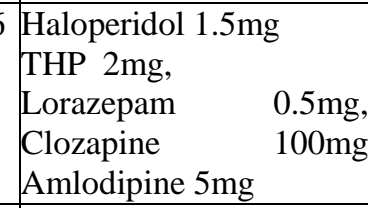 & $\begin{array}{l}\text { The patient had enough rest, irritability, } \\
\text { worried expression, directed behavior, at } \\
\text { will, pacing, risk of violent behavior, sensory } \\
\text { perception }\end{array}$ & $125 / 83$ & & 103 & \\
\hline 7 & 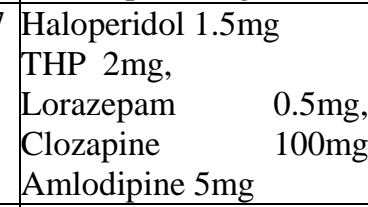 & $\begin{array}{l}\text { The patient was unstable and spoke harshly, } \\
\text { had adequate rest, the risk of violent behavior } \\
\text { and sensory perception disorders, lack of } \\
\text { nutrition, and good food intake }\end{array}$ & $113 / 97$ & 20 & 91 & 36.5 \\
\hline 8 & $\begin{array}{l}\text { Haloperidol } 1.5 \mathrm{mg} \\
\text { THP 2mg, }\end{array}$ & $\begin{array}{l}\text { The itching on the patient's cheeks improved. } \\
\text { The patient wanted to take morning }\end{array}$ & & & & \\
\hline
\end{tabular}




\begin{tabular}{|c|c|c|c|c|c|c|}
\hline & $\begin{array}{|lr|}\text { Lorazepam } & 0.5 \mathrm{mg}, \\
\text { Clozapine } & 100 \mathrm{mg} \\
\text { Amlodipine 5mg } & \\
& \end{array}$ & $\begin{array}{l}\text { medication such as haloperidol } 5 \mathrm{mg} \text {, and } \\
\text { lorazepam 0.5, while in the evening } \\
\text { haloperidol } 5 \mathrm{mg} \text {, THP } 2 \mathrm{mg} \text {, and clozapine } \\
\text { 100mg. There was a synergy drug interaction } \\
\text { between lorazepam and clozapine, with the } \\
\text { risk of cardiorespiratory cholars. Clozapine } \\
\text { increased the QT interval, where there was an } \\
\text { antidopaminergic effect. }\end{array}$ & & & & \\
\hline 9 & 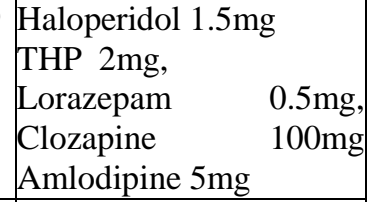 & $\begin{array}{l}\text { The patient was still autistic, irritable, and } \\
\text { suspicious, had lots of requests, adequate } \\
\text { rest, and was not motivated yet. The risk of } \\
\text { violent behavior and sensory perception } \\
\text { disorders was still there. }\end{array}$ & $131 / 75$ & 18 & 89 & \\
\hline 10 & $\begin{array}{|ll|}\text { Haloperidol } 1.5 \mathrm{mg} \\
\text { THP 2mg, } \\
\text { Lorazepam } & 0.5 \mathrm{mg}, \\
\text { Clozapine } & 100 \mathrm{mg} \\
\text { Amlodipine } & 5 \mathrm{mg}\end{array}$ & $\begin{array}{l}\text { The patient became autistic, irritable, } \\
\text { suspicious, demanded, rested, unmotivated, } \\
\text { and risked violent behavior. Furthermore, } \\
\text { the patient was autistic, pacing back and } \\
\text { forth, talking to herself, sleeping, diet } 1 / 2\end{array}$ & $122 / 78$ & & 81 & \\
\hline $11-13$ & $\begin{array}{|ll|}\text { Haloperidol } 1.5 \mathrm{mg} \\
\text { THP 2mg, } \\
\text { Lorazepam } & 0.5 \mathrm{mg}, \\
\text { Clozapine } & 100 \mathrm{mg} \\
\text { Amlodipine } & 5 \mathrm{mg} \\
\end{array}$ & $\begin{array}{l}\text { The patient could sleep enough in the next } \\
\text { two days, autistic, at will, pacing, guided, } \\
\text { signs of negative, violent behavior }\end{array}$ & $126 / 75$ & & 86 & \\
\hline 14 & \begin{tabular}{|l|} 
Haloperidol $1.5 \mathrm{mg}$ \\
Risperidone 2mg, \\
THP 2mg, \\
Clozapine 100mg, \\
valproic acid 250mg \\
Lorazepam stop \\
Risperidone regiven
\end{tabular} & $\begin{array}{l}\text { She, got enough sleep but still paced all night, } \\
\text { hallucination }\end{array}$ & $131 / 66$ & 20 & 88 & 36.3 \\
\hline $15-22$ & $\begin{array}{|lr|}\text { Haloperidol } & 1.5 \mathrm{mg} \\
\text { Risperidone } & 2 \mathrm{mg}, \\
\text { THP 2mg, } & \\
\text { Clozapine } & 100 \mathrm{mg} \\
\text { Valproic acid } & 250 \mathrm{mg}\end{array}$ & $\begin{array}{l}\text { The patient's condition was calm, cooperative } \\
\text { enough; and cooperative; hallucinations } \\
\text { sometimes appeared, and she had adequate } \\
\text { rest }\end{array}$ & $108 / 69$ & 18 & 92 & 36.1 \\
\hline 24 & $\begin{array}{l}\text { Take home medicine : } \\
\text { Risperidone 2mg, } \\
\text { Haloperidol } 1.5 \mathrm{mg}, \\
\text { THP } 2 \mathrm{mg}, \\
\text { Valproic acid 250mg } \\
\text { Clozapine } 100 \mathrm{mg}\end{array}$ & $\begin{array}{l}\text { By the time she went home on November } 28, \\
\text { the patient had enough sleep, was calm, } \\
\text { cooperative, and straight.; She wanted a diet, } \\
\text { drugs }\end{array}$ & $117 / 63$ & 18 & 100 & 36.1 \\
\hline
\end{tabular}

\section{DISCUSSION}

Risperidone is a second-generation antipsychotic. Its mechanism of action is to block 5-HT receptors and dopamine D2 antagonists. In the UK, risperidone is licensed to treat psychotic conditions with prominent positive and negative symptoms, for maintenance therapy in patients responsive to risperidone, and mania in bipolar disease [4]. In Indonesia, risperidone has a distribution license for acute and chronic psychosis and mania [8].

For the first time, the drug given to this patient was a combination of 3 antipsychotics, namely risperidone, clozapine, and haloperidol. The use of a combination of 3 antipsychotics is common, which is tailored to the patient's condition [9]. Clozapine was most likely given as the patient showed no response or responded partially to other antipsychotics. The use of 3 antipsychotics in this patient was due to the patient's restless condition, lack of sleep. Risperidone, clozapine, and haloperidol can overcome patient agitation. Combinations of these three drugs are allowed in cases of unresponsive or partial response patients $[3,10]$.

When clozapine was stopped, the patient experienced deterioration in condition, and agitation led to violent behavior. The patient was still given risperidone and haloperidol. The patient had xerosis on the second day after therapy. Xerosis is a condition in which the skin becomes dry, rough, scaly, and easily peels off. Xerosis usually occurs due to a lack of moisture and hydration in the skin. The contributing factors include age, conditions of menopause, and the use of certain drugs. Xerosis is a secondary feature of 
many conditions. Risperidone is the only precipitating factor for various causes of xerosis. Based on tracing medical records, it was found that the patient did not have diabetes, which was a risk factor for xerosis, the patient also did not take diuretics, and there was no history of psoriasis [11,12]. Tracing drug interactions also did not reveal the possibility of xerosis. From the literature study, the most likely cause of xerosis is risperidone. On evaluation with the Naranjo scale, we obtained score fpr risperidone was 6 (probable association between drug and side-effects), and for clozapine, THP, haloperidol were 2 (possible)[13]. The mechanism which risperidone causes xerosis is not known.

The incidence of xerosis with risperidone was not known with certainty, only $<1 \%$ was mentioned, so it is a rare side effect $[4,14]$. The patient's xerosis improved with facial lotion therapy and discontinuation of risperidone. Risperidone was just given back on November 18 (1-day discontinuation). Risperidone was regiven as the patient still having hallucinations with clozapine and haloperidol.

Another side effect of risperidone that occurred in this patient was tachycardia. On table. 1 we can see the patient experienced an increase in heart rate $(95 \mathrm{x} /$ minute to $124 \mathrm{x} /$ minute) Tachycardia has an incidence of $1 \%-5 \%$ in adults and can occur immediately after drug administration. In the Turkoz study, et al., tachycardia's incidence rate was $1 \%$ with risperidone $2-4 \mathrm{mg} /$ day and increased to $3 \%$ at $4-$ $6 \mathrm{mg} /$ day. The likelihood of tachycardia might increase if the dose increased [14-16].

These two side effects were not the significant side effects of risperidone but occurred in this patient. In the case of the patients in this study, the xerosis and tachycardia improved after discontinuation of risperidone.

When risperidone stopped, clozapine was given as the patient still experience hallucinations. Once the patient rested sufficiently, lorazepam discontinued. The patient was given valproic acid to control the patient's aggressive condition. Valproic acid interacts with risperidone and can increase risperidone toxicity, so close monitoring is warranted [14] The patient went home on November 28th with home medication risperidone, haloperidol, valproic acid, clozapine, and THP. This condition requires counseling from a pharmacist regarding possible recurrence of side effects, increased risperidone toxicity, and patient's non-compliance. In table 1, it can be seen that an increase in heart rate began to be seen after risperidone was given again on day 14 (Pulse $=88 \mathrm{x} /$ minute) to $100 \mathrm{x} /$ minute on return. Furthermore, counseling should involve the patient and the patient's family.

\section{CONCLUSION}

In this patient, xerosis and tachycardia were found, which were side effects of risperidone. Pharmacists should closely monitor these side effects because risperidone was regiven

\section{AUTHORS' CONTRIBUTIONS}

All authors contributed to data collection, data analysis, and writing of this manuscript

\section{ACKNOWLEDGMENTS}

The researchers would like to thank the Research and Community Service Institute of Universitas Muhammadiyah Yogyakarta for funding. Our gratitude also goes to Ghrasia Hospital for providing research data.

\section{REFERENCES}

[1]. WHO. Schizophrenia [Internet]. 2019 [cited 2020 Aug 27]. Available from: https://www.who.int/newsroom/fact-sheets/detail/schizophrenia

[2]. Remington G, Addington D, Honer W, Ismail Z, Raedler T, Teehan M. Guidelines for the Pharmacotherapy of Schizophrenia in Adults. The Canadian Journal of Psychiatry. 2017 Sep;62(9):60416.

[3]. Keepers GA, Fochtmann LJ, Dahl D, Dave B, Eyler E, Hanson AL, et al. THE AMERICAN PSYCHIATRIC ASSOCIATION PRACTICE GUIDELINE FOR THE TREATMENT OF PATIENTS WITH SCHIZOPHRENIA. 2020;414.

[4]. British National Formulary RPS. BNF-73-2017.pdf [Internet]. 2017 [cited 2020 Nov 7]. Available from: https://vnras.com/wp-content/uploads/2017/06/BNF73-2017.pdf

[5]. Chaves KM, Serrano-Blanco A, Ribeiro SB, Soares LAL, Guerra GCB, do Socorro Costa Feitosa Alves M, et al. Quality of Life and Adverse Effects of Olanzapine Versus Risperidone Therapy in Patients with Schizophrenia. Psychiatric Quarterly. 2013 Mar;84(1):125-35.

[6]. Fujian Song. Risperidone in the treatment of schizophrenia: a meta-analysis of randomized controlled trials. Journal of Psychopharmacology. 1997 Jan;11(1):65-71.

[7]. ICD-10 Version:2019 [Internet]. 2019 [cited 2020 Sep 10]. Available from: https://icd.who.int/browse10/2019/en\#/F20-F29

[8]. Badan Pengawas Obat dan Makanan PION. Risperidon | PIO Nas [Internet]. 2020 [cited 2020 Nov 4]. Available http://pionas.pom.go.id/cari/konten/risperidone

[9]. Gallego JA, Bonetti J, Zhang J, Kane JM, Correll CU. Prevalence and correlates of antipsychotic polypharmacy: A systematic review and metaregression of global and regional trends from the 1970s 
to 2009. Schizophrenia Research. 2012 Jun;138(1):1828.

[10]. Ostinelli EG, Hussein M, Ahmed U, Rehman F, Miramontes K, Adams CE. Risperidone for psychosisinduced aggression or agitation (rapid tranquillisation). Cochrane Schizophrenia Group, editor. Cochrane Database of Systematic Reviews [Internet]. 2018 Apr 10 [cited 2020 Sep 22]; Available from: http://doi.wiley.com/10.1002/14651858.CD009412.pu b2

[11]. Badiu D, Luque R, Rajendram R. Effect of Olive Oil on the Skin. In: Olives and Olive Oil in Health and Disease Prevention [Internet]. Elsevier; 2010 [cited 2020 Nov 7]. p. 1125-32. Available from: https://linkinghub.elsevier.com/retrieve/pii/B9780123 744203001236

[12]. Patel GA, Ragi G, Lambert WClark, Schwartz RA. Skin Disease and Old Age. In: Brocklehurst's Textbook of Geriatric Medicine and Gerontology [Internet]. Elsevier; 2010 [cited 2020 Nov 7]. p. 801-9. Available from: https://linkinghub.elsevier.com/retrieve/pii/B9781416 062318100959

[13]. Naranjo CA, Busto U, Sellers EM, Sandor P, Ruiz I, Roberts EA, et al. A method for estimating the probability of adverse drug reactions. Clinical Pharmacology and Therapeutics. 1981 Aug;30(2):23945 .

[14]. Lacy CF, Armstrong LL, Goldman MP, Lance LL. Drug Information Handbook, 27th Edition.chm. 27th ed. Lexi-Comp.Inc; 2018.

[15]. Tan HH, Hoppe J, Heard K. A systematic review of cardiovascular effects after atypical antipsychotic medication overdose. The American Journal of Emergency Medicine. 2009 Jun;27(5):607-16.

[16]. Turkoz I, Bossie CA, Lindenmayer J-P, Schooler N, Canuso CM. Paliperidone ER and oral risperidone in patients with schizophrenia: a comparative database analysis. BMC Psychiatry [Internet]. 2011 Dec [cited 2020 Nov 8];11(1). Available from: https://bmcpsychiatry.biomedcentral.com/articles/10.1 186/1471-244X-11-21 